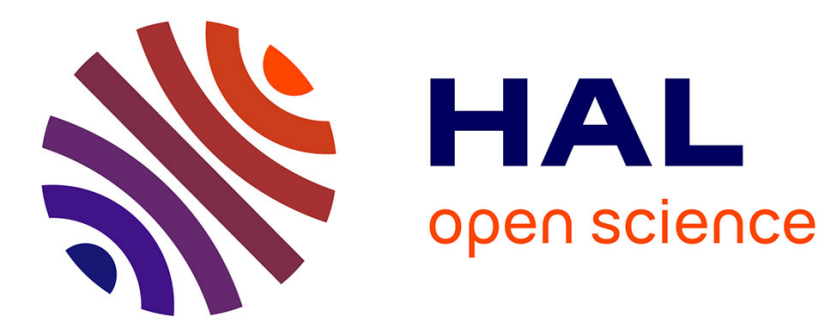

\title{
Comparative leaf decomposition within the holm oak complex
}

\author{
Nassima Sadaka-Laulan, Jean-François Ponge
}

\section{To cite this version:}

Nassima Sadaka-Laulan, Jean-François Ponge. Comparative leaf decomposition within the holm oak complex. European Journal of Soil Biology, 2000, 36 (2), pp.91-95. 10.1016/S1164-5563(00)01050-5 . hal-00501870

\section{HAL Id: hal-00501870 \\ https://hal.science/hal-00501870}

Submitted on 12 Jul 2010

HAL is a multi-disciplinary open access archive for the deposit and dissemination of scientific research documents, whether they are published or not. The documents may come from teaching and research institutions in France or abroad, or from public or private research centers.
L'archive ouverte pluridisciplinaire HAL, est destinée au dépôt et à la diffusion de documents scientifiques de niveau recherche, publiés ou non, émanant des établissements d'enseignement et de recherche français ou étrangers, des laboratoires publics ou privés. 
Title: COMPARATIVE LEAF DECOMPOSITION WITHIN THE HOLM OAK COMPLEX

\section{Authors: Nassima SADAKA-LAULAN ${ }^{1}$ and Jean-François PONGE 2}

Address of the authors:

1 Université Cadi Ayyad, Faculté des Sciences-Semlalia, Département de Biologie, UFR: Ecologie et Fonctionnement des Ecosystèmes Terrestres, Boulevard Prince My Abdallah, BP 2390, 40000 Marrakech (Morocco)

2 Museum National d'Histoire Naturelle, Laboratoire d'Écologie Générale, 4 avenue du Petit-Château, 91800 Brunoy (France)

Running title: Comparative decomposition

Number of text pages: 11

Number of tables: 2

Number of figures: 1

*Corresponding author: Museum National d'Histoire Naturelle, Laboratoire d'Écologie Générale, 4 avenue du Petit-Château, 91800 Brunoy (France) fax: +33 1 60-46-50-09; E-mail: jean-francois.ponge@wanadoo.fr 


\section{COMPARATIVE LEAF DECOMPOSITION WITHIN THE HOLM OAK COMPLEX}

\section{DECOMPOSITION COMPARATIVE DES FEUILLES AU SEIN DU COMPLEXE CHENE VERT}

\section{SADAKA-LAULAN N., and PONGE J.F.}

Abstract: The decomposition of holm oak leaves was compared using material embracing the genetical range of the holm oak complex. Collection sites were located in Morocco (Quercus rotundifolia), in the French Provence (Q. ilex), and in the French Languedocian Coast (Q. ilex $\mathrm{x}$ rotundifolia). Leaves (living and senescent) were taken directly on the tree and in the litter at five decomposition stages. The areal weight was used to follow the loss in weight of leaves in the course of their senescence then of their decomposition, in order to overcome limitations of the litterbag method. Leaves of Quercus rotundifolia had a higher areal weight in their living stage but they lost more weight in the course of decomposition than leaves of $Q$. ilex. Leaves from hybrid populations had an intermediary behaviour. All three populations of leaves exhibited an increase in weight during senescence. At the white-rot stage (stage V), leaves of every origin reached a similar areal weight. Reasons for the observed resemblances and discrepancies have been discussed to the light of existing knowledge. Our results give additional strength to the separation of $Q$. ilex and $Q$. rotundifolia as two distinct species, with possible introgression and hybridization in contact zones.

Key words : Quercus ilex/ Quercus rotundifolial $Q$. ilex x rotundifolial leaf areal weight/ litter/ decomposition. 
Résumé: L'étude comparée de la décomposition des feuilles de chêne vert a été réalisée sur du matériel provenant du complexe "chêne vert. Les sites d'étude sont localisés au Maroc pour Quercus rotundifolia et en France, d'une part en Provence pour $Q$. ilex, et d'autre part au Languedoc pour $Q$. ilex x rotundifolia. Le poids surfacique a été utilisé pour suivre la perte pondérale des feuilles aussi bien au cours de leur sénescence qu'au cours de leur décomposition, dans le but de surmonter les limites de la méthode des sacs de litière. Les feuilles vivantes de $Q$. rotundifolia, bien qu'ayant un poids surfacique plus élevé que celui de $Q$. ilex, perdent plus de poids au cours de la décomposition. Les feuilles issues des populations hybrides occupent une position intermédiaire. Au stade V (feuilles blanchies) les feuilles des trois provenances atteignent le même poids surfacique. Les similitudes et les différences observées sont discutées à la lumière des connaissances existantes. Nos résultats apportent un élément supplémentaire à la distinction des deux espèces, $Q$. ilex et $Q$. rotundifolia, avec un génotype intermédiaire provenant d'une zone d'introgression et d'hybridation entre les deux taxons.

Mots clés : Quercus ilex/ Quercus rotundifolia/ Q. ilex x rotundifolia/ poids surfacique/ litière/ décomposition. 


\section{INTRODUCTION}

Holm oak is an evergreen Mediterranean oak species known for the complexity of its taxonomic status, due to high genetical and ecological plasticity [2, 3, 13, 21, 27, 35]. Its variability has been studied at the scale of populations, of individuals, and even at the scale of a ramus [13].

Lamarck [10], followed by Schwartz [30], described two distinct species, namely Quercus ilex L. and $Q$. rotundifolia Lam. Differential anatomical features of $Q$. ilex are oblong, slender leaves, with few spines, and bitter acorns. Leaves of $Q$. rotundifolia are round-shaped, with numerous spines, its acorns are bigger and they have a soft taste. Saenz De Rivas [27, 28] states that these taxa should be considered only as sub-species, on the basis of statistical analysis of leaf hair and shape, thus reinforcing Morais [18] opinion. Conversely Saenz De Rivas [29] considers them as true distinct species, on the basis of pollen morphology. Madjidieh [13, 14] compared leaf anatomical features using both TEM and light microscopy and concluded them to be synonymous.

Ecological research added some interesting differential characters. Achhal et al. [1] observed that $Q$. ilex was much less climate tolerant than $Q$. rotundifolia. In Morocco, $Q$. ilex is limited to mild, moist places under Mediterranean climate, while $Q$. rotundifolia tolerates colder, dryer climate conditions. This may partly explain differences in their geographical distribution, $Q$. rotundifolia being common in western Mediterranean countries (Morocco, Algeria, Tunisia, Central Spain), mostly in mountains, while $Q$. ilex is restricted to a coastal fringe, and remains alone in eastern Mediterranean countries. There exists a wide overlapping zone in the South of France, mostly along the Languedocian Coast where both taxa live in mixed populations [3].

Recognition of nearby species only on the basis of morphological, phenological and ecological features is not very easy, being often disputed. This encouraged scientists to select other, more ecologically stable criteria, such as enzymes $[2,17]$ and plant secondary metabolites [21], which enabled to separate definitely $Q$. rotundifolia from $Q$. 
ilex. Nevertheless hybridization between these two species still occurs, as along the Languedocian Coast $[3,17,35]$.

Our contribution to this still debated question has been to follow the decomposition of their leaves in field conditions, comparing true $Q$. ilex and $Q$. rotundifolia with individuals living in mixed populations. Rather than using litterbags, which are known to largely influence the decomposer activity [31], we preferred to compare still attached leaves and fallen leaves belonging to five stages of decomposition, by measuring changes in their leaf areal weight [26]. A previous study dealt with $Q$. ilex [26]. In the present study a comparison was made with new data concerning $Q$. rotundifolia from Morocco and $Q$. ilex x rotundifolia from the Languedocian Coast.

\section{METHODS}

\subsection{Sites}

Leaf collection was done in June 1998, at the time of the optimum litter fall [11]. Sites were located in Morocco (Toufliht, northern slope of Higher Atlas) and France (Gardiole de Rians, Provence, and Montpellier, Languedoc). Table I indicates main environmental conditions prevailing at the collection sites.

\subsection{Material}

Leaves were collected directly on the tree and in litter horizons. Still attached leaves were separated into living (green) and senescent (yellow) leaves, notwithstanding their age. The mean duration of life of holm oak leaves (Languedocian Coast) has been estimated as two years, but leaf fall may occur during their $1^{\text {st }}$ as well as during their $3^{\text {rd }}$ year of life [25]. Leaves from litter horizons were divided into 5 stages of decomposition according to morphological criteria (table II). We studied 200 leaves for each of the seven stages and for each species, only means and standard erors being presented here. 


\subsection{Measurements}

Leaves were washed then brushed in order to remove adhering mineral particles. The distal part of leaf blades was stamped once with a $6 \mathrm{~mm}$ diameter copper punch, avoiding the main nerve. Leaf disks were oven-dried at $105^{\circ} \mathrm{C}$ during $48 \mathrm{~h}$, then weighed. The individual mass of leaf disks was used to derive the leaf areal weight $\left(\mathrm{mg} . \mathrm{cm}^{-2}\right)$, i.e. the weight per unit surface of leaf (one side only being accounted for).

\section{RESULTS}

Two phases can be distinguished in the comparable patterns of aerial weight changes of $Q$. ilex, $Q$. rotundifolia and hybrid holm oak leaves (figure 1 ). There is an increase in the leaf areal weight from living to stage I leaves $(12 \%, 9 \%$, and $14 \%$ for $Q$. ilex, $Q$. rotundifolia and hybrid, respectively), followed by a decrease until stage IV (19\%, 37\%, and $28 \%$ for $Q$. ilex, $Q$. rotundifolia and hybrid, respectively). The weight of senescent leaves (not measured in $Q$. ilex) does not greatly differ from that of stage I leaves. Stage V was collected only for $Q$. rotundifolia and hybrid holm oak. From stage IV to stage V leaves still lose weight (43\% and $25 \%$ for Q. rotundifolia and hybrid, respectively).

The three studied populations greatly differ in their leaf area weight. Living leaves of $Q$. rotundifolia are heavier ( $\left.15.98 \pm 0.21 \mathrm{mg} . \mathrm{cm}^{-2}\right)$, than those of $Q$. ilex ( $\left.9.57 \pm 0.15 \mathrm{mg} . \mathrm{cm}^{-2}\right)$, hybrid individuals being intermediary $\left(12.63 \pm 0.14 \mathrm{mg} . \mathrm{cm}^{-2}\right)$. They differ also in their decomposition dynamics. The weight loss rate from living leaves to stage IV is $10 \%, 31 \%$, and $19 \%$ for $Q$. ilex, Q. rotundifolia, and hybrid, respectively. If stage $\mathrm{V}$ is included in our calculations the weight loss rate reaches $61 \%$ and $39 \%$ for $Q$. rotundifolia and hybrid holm oak, respectively. It can be pointed out that, despite strong differences in leaf areal weight between the three studied populations, areal weight values converge towards $7 \mathrm{mg} \cdot \mathrm{cm}^{-2}$ at stage V. This value seems convenient for $Q$. ilex, too, suppose we lengthen its decomposition curve (figure 1). 


\section{DISCUSSION}

The increase in weight observed from living to senescent leaves could have been attributed to the sampling procedure used. The collection of living leaves included $1^{\text {st }}$ to $3^{\text {rd }} \mathrm{yr}$ or even still older leaves, thus leaves which are far from fall (too young) as well as leaves prone to senesce then fall within a few months. In fact, as this has been demonstrated by Sadaka [26], holm oak (Q. ilex) leaves lose areal weight during their development. Thus the observed increase in weight from living to senescent leaves has been probably underestimated and cannot be explained by a sampling bias. Rather it is hypothesized that tannins, which oak leaves have accumulated during their entire life $[24,26]$, will become totally or partly oxidized during the senescence of foliage [8], which will increase the areal weight of leaves before they fall.

Although climate conditions do not differ markedly between the three study sites (table I), strong differences have been registered in the decomposition curves of members of the holm oak complex (figure 1). Several reasons could be invoked to explain this phenomenon. The decomposition of leaf litter is controlled, not only by physical factors such as temperature and moisture, which may act upon decomposer communities [15], but also by litter quality, defined by its $\mathrm{C}: \mathrm{N}$ ratio [33], its lignin and tannin content $[6,7,16,19]$, as well as its content in nutrients such as $\mathrm{N}, \mathrm{Ca}$ and $\mathrm{P}[7$, 16, 32]. In addition, the toughness of leaves may affect their decomposition rate [9], and this should be considered when trying to explain the observed differences. Living leaves of $Q$. rotundifolia are slightly thicker in average than those of hybrid individuals. This could be explained by drier summer conditions in Toufliht (Morocco), where the period without rain exceeds that in Montpellier (France) by several months. The xerophytic character of $Q$. rotundifolia may be related to this difference in blade thickness.

Despite a higher initial areal weight, leaves of $Q$. rotundifolia decay at a higher rate than that of $Q$. ilex, reaching a similar areal weight at stages IV and V (figure 1). This could be explained by more total precipitation in Toufliht, mostly distributed from October to February, which could be favourable for decomposer activity (microbes, 
fauna) in winter periods, directly and by increasing the leaching of distasteful or toxic substances $[20,22]$.

It is considered that differences in leaf areal weight between French (Provence) and Morocco populations allow the consideration of $Q$. ilex and $Q$. rotundifolia as two distinct species. Languedocian populations are living in a zone of hybridization and introgression between these two species.

The advantage of the method used for measuring litter decomposition, compared to the widely used litterbag method $[4,5]$, lies on the absence of perturbation of the decaying material. Nothing else than weighing different leaf categories collected once is necessary for assessing differences in decomposing ability between plant species and/or between sites. In addition, the exclusion of macrofauna from small-mesh nets prevents results from litterbag studies to be used when comparing sites of varying quality [23]. Witkamp \& Olson [34] found two to three times more loss in weight in unconfined compared to confined litter. St John [31] observed that the number of fungal propagules colonizing the confined substrate was lower than when the substrate was unconfined. Microclimate conditions may be also strongly affected by the confinement of litter, for instance litterbags increase the moisture content of leaves [12]. All these shortcomings argue for the abandonment of the use of litterbags, more especially for decomposition studies in Mediterranean countries where i) macroinvertebrates are abundant, ii) decomposition is mainly limited by dryness of the litter during summer months.

\section{Acknowledgements}

Authors are greatly indebted to Pr. M. Rapp, and Dr. C. Collin, CNRS, Montpellier, France, for kind disposal of leaf material and climate data from the Languedocian Coast site. 


\section{REFERENCES}

[1]Achhal A., Akabli O., Barbero M., Benabid A., M'hirit A., Peyre C., Quezel P., Rivas-Martinez S., A propos de la valeur bioclimatique et dynamique de quelques essences forestières au Maroc, Ecol. Medit. 5 (1980) 211-248.

[2]Afzal-Rafii Z., Caractéristiques taxonomique, morphologique et isoenzymatique du complexe "Chêne vert", Bull. Soc. Bot. Fr. 135 (1988) 343-352.

[3]Barbero M., Loisel R., Le chêne vert en région méditerranéenne, Rev. For. Fr. 32 (1980) 531-543.

[4]Berg B., Cortina J., Nutrient dynamics in some decomposing leaf and needle litter types in a Pinus sylvertris forest, Scand. J. For. Res. 10 (1995) 1-11.

[5]Bocock K.L., Gilbert O.J.W., The disappearance of leaf litter under different woodland conditions, Plant Soil 9 (1957) 179-185.

[6]Fogel R., Cromack K.JR., Effect of habitat and substrate quality on Douglas fir litter decomposition in Western Oregon, Can. J. Bot. 55 (1977) 1632-1640.

[7]Gallardo A., Merino J., Control of leaf litter decomposition rate in a Mediterranean shrublands as indicated by N, P, and lignin concentrations, Pedobiologia 43 (1999) 6472.

[8]Gallet C., Apports de la biochimie à la connaissance du fonctionnement des écosystèmes forestiers: rôle des composés phénoliques dans une pessière à myrtille, Thèse de Doctorat, Université de Lyon, 1992, 279p + annexes.

[9]King H.G.C., Heath G.W., The chemical analysis of small samples of leaf material and the relationship between the disappearance and composition of leaves, Pedobiologia 7 (1967) 192-197.

[10]Lamarck J. B. de., Botanique, Panckoucke, Paris, 1783.

[11]Lossaint P., Rapp M., La forêt méditerranéenne de chênes verts, in: Lamotte M., Bourlière F. (Eds.), Problèmes d'écologie, Ecosystèmes terrestres, Masson, Paris, 1978, pp. 129-185.

[12]Lousier J.D., Parkinson D., Litter decomposition in a cool temperate deciduous forest, Can. J. Bot. 54 (1976) 419-436. 
[13]Madjidieh H., Étude taxonomique comparée de Quercus ilex L. et Quercus rotundifolia Lamk., Bull. Soc. Linn. Provence 35 (1985) 87-98.

[14]Madjidieh H., Les poils des feuilles de Quercus ilex L. (s.1.): structure microscopique et rôle taxonomique, Bull. Soc. Linn. Provence 37 (1986) 109-124.

[15]Meentemeyer V., Macroclimate and lignin control of litter decomposition rates, Ecology 59 (1978) 465-472.

[16]Melillo J.M., Aber J.D., Muratore J.F., Nitrogen and lignin control of hardwood leaf litter decomposition dynamics, Ecology 63 (1982) 621-626.

[17]Michaud H., Toumi L., Lumaret R., Li T.X., Romane F., Di Giusto F., Effect of geographical discontinuity on genetic variation in Quercus ilex L. (holm oak). Evidence from enzyme polymorphism, Heredity 74 (1995) 590-606.

[18]Morais T., Novas áreas da fitogeografia portuguesa, Bol. Soc. Broteriana Sér. 214 (1940) 97-138.

[19]Nicolai V., Phenolic and mineral content of leaves influences decomposition in European forest ecosystems, Oecologia 75 (1988) 575-579.

[20]Nykvist N., Leaching and decomposition of water soluble organic substrates from different types of leaf and needle litter, Stud. For. Suecica 3 (1963) 1-29.

[21]Pelleau Y., Biodiversité du chêne vert en région méditerranéenne Quercus ilex L., Quercus rotundifolia Lam.: étude de la variabilité morphologique, chimique et écologique, Thèse de Doctorat, Université Aix-Marseille III, 1991, 122p + annexes. [22]Poinsot-Balaguer N., Racon L., Sadaka N., Le Petit J., Effects of tannin compounds on two species of Collembola, Eur. J. Soil Biol. 29 (1993) 13-16.

[23]Ponge J.F., Arpin P., Sondag F., Delecour F., Soil fauna and site assessment in beech stands of the Belgian Ardennes, Can. J. For. Res. 27 (1997) 2053-2064.

[24]Racon L., Sadaka N., Gil G., Le Petit J., Matheron R., Poinsot-Balaguer N., Sigoillot J.C., Woltz P., Histological and chemical changes in tannic compounds of evergreen oak leaf litter, Can. J. Bot. 66 (1988) 663-667. 
[25]Rapp M., Production de litière et apport au sol d'éléments minéraux dans deux écosystèmes méditerranéens: la forêt de Quercus ilex L. et la garrigue de Quercus coccifera L., Oecol. Plant. 4 (1969) 377-410.

[26]Sadaka N., Contribution à l'étude des relations trophiques Collemboles - feuilles de chêne vert - microorganismes, Thèse de troisième cycle, Université de Provence, 1986, $134 \mathrm{p}$.

[27]Saenz De Rivas C., Estudios sobre Quercus ilex L. y Quercus rotundifolia Lamk., An. Inst. Bot. A.J. Cavanilles 25 (1967) 245-262.

[28]Saenz De Rivas C., Biometria foliar de una poblacion de Quercus ilex L. subsp. rotundifolia (Lam.) T. Morais, en El Pardo (Madrid), An. Jard. Bot. Madrid 27 (1970) 107-114.

[29]Saenz De Rivas C., Estudios palinologicos sobre Quercus de la Espana mediterranea, Bol. R. Soc. Esp. Hist. Nat. Sér. Biol. 71 (1973) 315-329.

[30]Schwartz O., Quercus, in : Tutin T.G., Heywood V.H., Burges N.A., Valentine D.H., Walters S.M., Webb D.A., (Eds.), Flora Europaea, University Press, Cambridge, 1964, Vol. 1, pp. 61-64.

[31]St John T.V., Influence of litterbags on growth of fungal vegetative structures, Oecologia 46 (1980) 130-132.

[32]Van Cleve K., Organic matter quality in relation to decomposition, in : Holding A.J., Heal O.W., Mc Clean S.F. JR., Flanagan P.W. (Eds), Soil organisms and decomposition in tundra, Tundra Biome Steering Committee, Stockholm, 1974, pp. 311-324.

[33]Witkamp M., Decomposition of leaf litter in relation to environment, microflora and microbial respiration, Ecology 47 (1966) 194-201.

[34]Witkamp M., Olson J.S., Breakdown of confined and nonconfined oak litter, Oïkos 14 (1963) 138-147.

[35]Yacine A., Une étude d'organisation de la diversité génétique inter- et intrapopulation chez le chêne vert: Quercus ilex L., Thèse de Doctorat, Université de Montpellier,1987,115p. 
Table I. Main ecological conditions in the three collection sites.

\begin{tabular}{|l|c|c|c|}
\hline & Q. rotundifolia \\
Toufliht, Morocco & $\begin{array}{l}\text { Q. ilex } \\
\text { Gardiole de Rians, } \\
\text { France (Sadaka, 1986) }\end{array}$ & $\begin{array}{c}\text { Q. ilex_x rotundifolia } \\
\text { Montpellier, France }\end{array}$ \\
\hline Altitude (m) & 1540 & 620 & 56 \\
Aspect & N-NE & NE & S \\
Mean annual rainfall (mm) & 840 & 747 & 793 \\
Relief & Very rough & Rough & Level \\
Substrate & Sandstone and clay & Compact limestone & Clay \\
pH & 5,7 & 6,7 & 7,3 \\
Vegetation & Dense forest & Dense forest & Clump of trees \\
Bioclimate & Subhumid to semiarid & Humid to subhumid & Humid to subhumid \\
\hline
\end{tabular}

Table II. Morphological features of the five decomposition stages for holm oak leaf litter.

\begin{tabular}{|l|l|}
\hline Stage I & Yellow, externally intact, thick, hard, lower side densely covered with green hairs \\
\hline Stage II & $\begin{array}{l}\text { Yellow, slightly decayed but still thick and hard, hairs cover on the lower side invaded } \\
\text { by fungi }\end{array}$ \\
\hline Stage III & Brown, thin, soft, decayed, a few hairs still present \\
\hline Stage IV & Brown, thin, very soft, strongly decayed but still recognizable, no hair present \\
\hline Stage V & Bleached, very thin, brittle and more or less aggregated by fungal mycelium \\
\hline
\end{tabular}




\section{Legend of figure}

Fig. 1. Leaf areal weight (mean \pm standard error) of holm oak leaves at varying senescence and decomposition stages 


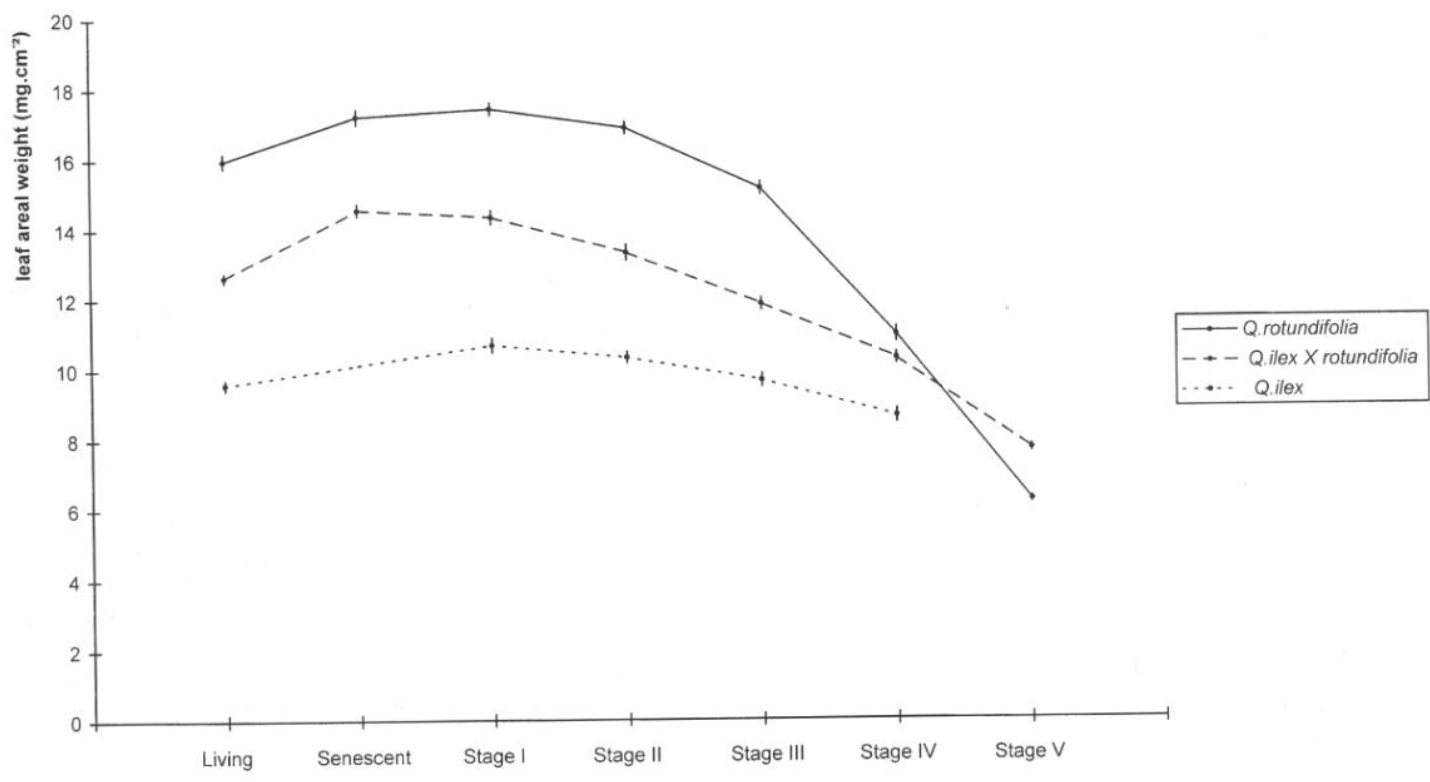

1

2 Fig. 1 